\title{
A Comparative Study to Determine the Occupational Stress Level and Professional Burnout in Special School Teachers Working in Private and Government Schools
}

\author{
Christopher Amalraj Vallaba Doss ${ }^{1}$, J. Joyce Rachel ${ }^{2}$, Mu'taman Khalil Jarrar ${ }^{1}$, \\ Mahdi S AbuMadini ${ }^{1,3}$ \& Muhil Sakthivel ${ }^{4}$ \\ ${ }^{1}$ Vice Deanship for Quality and Development, College of Medicine, Imam Abdulrahman Bin Faisal University, \\ King Fahd Hospital of the University, Dammam, Saudi Arabia \\ ${ }^{2}$ College of Occupational Therapy, Medical and Health Sciences, SRM University, Kattankulathur, Tamilnadu, \\ India \\ ${ }^{3}$ Department of Psychiatry, King Fahd Hospital of the University, Al-Khobar, Saudi Arabia \\ ${ }^{4}$ Quality Support Unit, Quality and Academic Accreditation, College of Medicine, Imam Abdulrahman Bin Faisal \\ University, Dammam, Saudi Arabia \\ Correspondence: Christopher Amalraj Vallaba Doss, Vice Deanship for Quality and Development, College of \\ Medicine, Imam Abdulrahman Bin Faisal University, P.O. Box 1982, Dammam 31441, Saudi Arabia. Tel: \\ 966-58-196-3915. E-mail: christopheramalraj@gmail.com; cadoss@iau.edu.sa
}

Received: December 21, 2017 Accepted: January 9, 2018 Online Published: January 30, 2018

doi:10.5539/gjhs.v10n3p42 URL: https://doi.org/10.5539/gjhs.v10n3p42

\begin{abstract}
Background and Objective: Healthy work environment is required to provide high quality teaching. Few studies regarding occupational stress and burnout in Indian schools have been conducted. The study aims to determine and compare the occupational stress level and professional burnout in teachers working in private and government schools. 120 private school teachers and 120 government school teachers recruited for this study.
\end{abstract}

Methods: Chi square test, Student independent $t$ test and ANOVA used for data analysis have been used.

Results: Stress level and burnout level are varies significantly between male and female Indian school. (Chi square value 26.27 and $p$ Value 0.001 in male and chi square value 38.06 and p value 0.001 in female). Government schools (Least Likely 5 \pm 0.0 , More Likely 10.82 \pm 1.99 , Most Prone Stress $16.15 \pm 1.84$ have significant difference among them) have higher stress level than Private schools (Least Likely 4.00 \pm 1.41 , More Likely 9.86 \pm 2.29 , Most Prone Stress $15.66 \pm 1.34$ have significant difference among them). Governmental schools having more stress $(14.33 \pm 3.24)$ compare to Private schools $(13.34 \pm 3.51),(t=2.26, p=0.023)$. Similarly the burnout also having the more in government schools $(59.43 \pm 11.78)$ compare to private schools $(48.61 \pm 11.94),(\mathrm{t}=7.07, \mathrm{p}=0.001)$.

Conclusions: The government teachers have more occupational stress compared to the private school teachers in India. Leaders and decision makers required to make early identification and counseling about different factors that influence stress level in private and Government school teachers.

Keywords: occupational stress, professional burnout, government school, private school, analysis of variances

\section{Introduction}

Today's life is full of challenges. Stress is the very important reaction that the organism displays against teaching environmental situation (Luthans et al., 1994). Stress, means for pressure that people are exposed to in their own life (Jepson \& Forrest, 2006). Stress is important problem for developed information societies but also for developing countries. Whenever, there may be differences in these countries in the sources of stress that people face and their degree of heath importance (Bhagat, Steverson, \& Segovis, 2007).

In today's scenario with the hustle and bustle in life stress is the most common thing which we can observe, reasons could be numerous but sometime the major would be the occupational stress. Work-related disability and productivity loss as a result of stress and depression are critical determinants of quality of life and contribute significantly to health burden (Lee et al., 2017) as well as indirect medical costs (Ho et al., 2013). As researches 
shows that our academic profession is also get affected by stress and positive relationship between occupational stress/burnout. Stress in academic level could be harmful if your mind is not properly centered how will you generate and impart the knowledge. In this research paper researcher try to find out the factors which act as a barrier in pedagogy which affect them physically, mentally and professionally and also assess what are the limitations of the existing research and database helps others to work on this direction (Buunk, 1998; Cydulka, Lyons, Moy, Shay, Hammer, \& Mathews, 1989; Naina, Deeya, Mohit, \& Arjun, 2015).

Professional stress of higher secondary school teachers, the female HSS teachers compare to more stress than the male higher secondary school teachers (Olive et al., 2016). The reason is that female teachers apart from guiding the terminal stage school students have to look after their family members, they were not able to allocate equal weight age to working as well as family environment, hence this result in enhanced stress level. Married higher secondary school teachers have more stress not compare to unmarried higher secondary school teachers because married teachers are shouldering more responsibility than the unmarried in terms of school work as well as in the family and society, hence they are in the position to satisfy all the dimensions, this results in higher levels of stress from the (Sapna \& Ved Prakash, 2013).

Higher secondary school teachers working in government schools have more stress than those working in private higher secondary schools because the government teachers have to fulfill the work and the task given to them time by time from the administration as well as from the government departments (Sunanda, 2017), hence they are more responsible to the government officials than the private school HSS teachers, hence a higher level of stress was evident in the government school teachers. Survey method was used for this study. The sample consisted of 200 post graduate teachers working in two different schools in and around Indian regions. The Occupational Stress Inventory was developed by Dr. Joseph and Dr. Dharmangadan. The five point scale consists of 37 test items are used in this study.

\section{Literature Review}

\subsection{Need and Significance of the Study}

Summarized as pre-existing mental health issues during university study (Cuttilian et al., 2016), low motivation among students,Stress sources of information, teachers may be summarized as low motivation among students, discipline, punctuality of time and the heavy work load, assessed by others, schools and colleague relationship, conflict and indefiniteness of roles, very bad working conditions and self-respect, students' behavior problems, not support of colleagues, family and friends (Detert, 2006). "Stress has been defines as the state manifested by the specific syndrome which consists of all the non-specific induced changes within a biological system (Kyriacou, 2001).

Stress was first coined in the biological word at 1930s, but now present decade commonly used in popular parlance. Stress is a feeling of human being reacts to particular action. The human body activating the nervous system and particular problem to facing. This natural action is known as stress response. The biological impact of chronic stress include depressive and anxiety-like behaviors as well as cognitive impairment (Yang et al., 2016) and negative impact on immune system (Lu et al., 2017) and the cardiovascular system (Ho et al., 2010). School teachers have pressure of dealing with so many children's activities in the schools and home at the same time they prepare the next class section (Selye, 1950).

There are some studies in India also regarding stress in school teachers - one done in south India for teachers of university and the other among school teachers in Rajasthan. But none of them used any recognized scale to measure stress. Our study is a significant difference in the outcome, addition to the teacher's stress and burnout through our results, especially in India where more relevant studies exist dealing with these problems. In addition, our study is aimed give an account of how the teachers of different schools and gender are occupying with the increased stress (Sumanta Dawn et al., 2016).

In general, burnout is a negative emotional experience for a person reacting with job related stress - (Selye, 1950). Burnout refers to a workers of widely understand human service occupations including teaching, cluster of physical, emotional and interactional symptoms that include emotional exhaustion, a sense of lacking personal accomplishment and depersonalization of clients- (Akcamete, 2001). Teachers have the stress of dealing with children but they are also educating and helping them to mold these children into high level people in the community. Whenever some rules, regulations, guidelines, performance of all the teachers can have very high levels of stress. Maladaptive Rumination interacts with life stress to predict depressive symptoms (Lu et al., 2014). High level of stress causes people to ascribe greater Global Journal of Health Science http://gjhs.ccsenet.org 5 internal responsibility in failure than in success due to higher level of self-blame (Yeo et al., 2017). 
There was an increase of the fact found that in the research linking occupational stress/ professional burnout of the school teachers in the Indian context. For example, studies conducted by (Maslach \& Jackson, 1981; Amirtagowri \& Thiagarajan, 2005; M. Kaur \& S. Kaur, 2007; Kumar, 2007; Reddy, 2007; Chopra, 2009; Reddy \& Poornima, 2012), which focused on occupational problems/stress of teachers working in primary/secondary/special schools. Centuries ago scientists recognized that work situation may have adverse health effects. They suggest that the involvement of medical science with work and health problems started with Hippocrates, as early as fifth century BC. A state of mental or emotional strain or tension resulting from adverse or demanding circumstances, (Poornima, Shveta, \& David, 2012).

The origin of the word stress can be traced to the old French word stressed meaning 'narrowness' or 'oppression' or the Latin word strict us earning 'drawn tight'. Professional stress manifests in a varied fashion including burnout, depression, anxiety, anger, irritability and/or substance abuse. This in turn affects the personal, interpersonal and social wellbeing of an individual which are conceptually referred as quality of life. Coping with job stress is difficult as it usually depends on a whole range of factors which may or may not be under an individual's control, (Buunk, 1998).

The research has been done in the private primary school and they concluded that stress level is more in private primary school (Reddy, 2012). Another study was done in the comparison of primary and secondary school and they concluded that stress level is more in primary school (Anbu, 2015). Our study have shown clearly demonstrated that the occupational stress level in teachers working in government/private schools for normal children have significant difference. Another study has recommended doing in the various cultures, based on responsibilities and the type of organization (Ansarul, 2014). Since special school teachers have more responsibilities in teaching special children. It is necessary to determine the occupational stress/burnout in special school teachers working in private/government school.

After review of some literature we have found that lots of work have been done on the occupational stress of a teacher in a different dimension in two different schools i.e. (S. Kaur, 2011) has find out the occupational stress among faculty members in higher education institution and the results showed that the determinants of stress among the administrators are numerous and varied. (Alexander, Gaillard, \& Wisner, 2012) Found that the primary school teachers are very highly stressed people, the private primary school teachers also found to be highly stressed in comparison to their government primary school teachers. (Chaly, 2014; Hasan, 2014) Results showed that there is difference in their stress and burnout.

\subsection{Conceptual Definition}

Occupational Stress: This study explore the compiles the occupation stress and burnout between the government and private schools. Occupational stress as disruption in an individual's physiological and psychological homeostasis that forces them to deviate from usual functioning in interaction with their jobs and work environment, (Allen, Hitt, \& Greer, 1982; Oshagbemi, 2000). Occupational stress can a terms of physical and psychological effects of occupation on an individual. Burnout: Stress leads to is known as burnout. The loss of interest, low frustration tolerance and apathy. Private School: A school supported by private organization or private individual. Government School: It's a free tax supported school controlled by a local authority.

\section{Method}

\subsection{Research Design}

It is a cross sectional quantitative design.

\subsection{Study Setting}

The study was conducted at Kanchipuram district of Tamilnadu state. Kanchipuram district has eight administrative sub divisions. Kanchipuram is considered one of the most education districts in Tamilnadu; Kanchipuram was selected for the study because it has enough number of government and private schools which are distributed. Also more developed district, it was considered as proper setting to conduct the study. The district has 456 schools at secondary level where 4302 teachers are working, 32 only secondary schools were selected for this study.

\subsection{Inclusion and Exclusion Criteria}

Inclusion Criteria: Both gender, school teachers in government and private schools in rural and urban areas.

Exclusion Criteria: School teachers who is not welling to participate in the study. Written consent form obtained from each individual. Questionnaires developed by other based on the need. Questionnaire was given to the special school teachers in both set up and asked to be filled. 


\subsection{Sampling and Population}

Convenient sampling method used. The population of the study is the school teachers in private and government school. Prepared the list of all schools in the Kanchipuram district. The list obtained from district office of Department of Education, Kanchipuram, and Tamilnadu. The latest list was obtained. The names of all schools of secondary level situated inside Kanchipuram district. Schools classified according to type of school (government or private). Out of 456 schools mentioned in the list, 258 were government schools and 198 were private schools selected. The comparative study was based on 100 special school teachers in both set ups, occupational stress questionnaire, burnout questionnaire. Data have been collected from private and government schools have some criteria for sample collection. Schools were selected by cluster random sampling technique. Based on this we selected 16 schools. And select the teacher in the simple random sampling technique. Cluster sampling method was adopted, because feasibility of the researcher.

\section{Data Analyses and Results}

Chi square test, Student independent $t$ test and ANOVA used for data analysis have been used.

Table 1, shows the number of male and female in the private school and government school, in this regards 43 male and 77 female in the private school and 43 male and 77 female in the government school. In this study $64.2 \%$ of female compare to $35.8 \%$ of male in private school, similar to the government school. The male population is lesser than the female population in the present study. Detalies regarding the Demographical information shown in the Appendix.

Table 1. The Gender wise distribution among the private and government school

\begin{tabular}{llllll}
\hline & Male & Female & Total & Chi Square Test & P Value \\
\hline Private School & $43(35.8)$ & $77(64.2)$ & 120 & 0.00 & 1.00 \\
Government School & $43(35.8)$ & $77(64.2)$ & 120 & $1 \mathrm{df}$ & NS \\
\hline
\end{tabular}

NS - Not statistical significance association between the private school and government school among the gender at $95 \%(\mathrm{p}>$ 0.05). Based on the gender cannot show the significance association difference in the two schools, because the number of People are equally taken, using the chi square test, the chi square value is 0.00 and the p value is 1.00 more than the 0.05 .

Table 2, shows more likely with no job stress $90 \%$, most prone stress with high amount of job related stress $87.5 \%$, Most prone stress with moderate amount of stress on the job 67.6\%, most prone stress with low amount of job related stress $65.2 \%$ and all others less than $50 \%$ among the male people have significance association presented in their stress levels and burnout levels. More likely with no job stress $77.8 \%$ is lesser than the male, more prone stress with high amount of job related stress $86.7 \%$ is lesser than the male, Most prone stress with moderate amount of stress on the job $72.5 \%$ is more than the male and all others less than the $50 \%$ among the female population have significance association present in their stress levels and burnout levels. 
Table 2. The association between the stress levels and burnout among the male and female

\begin{tabular}{|c|c|c|c|c|c|c|c|c|}
\hline \multirow[b]{2}{*}{ Sex } & \multirow[b]{2}{*}{$\begin{array}{l}\text { Stress } \\
\text { Levels }\end{array}$} & \multicolumn{5}{|c|}{ Burnout Levels } & \multirow[b]{2}{*}{$\begin{array}{l}\text { Chi } \\
\text { Square } \\
\text { Test }\end{array}$} & \multirow[b]{2}{*}{$\begin{array}{l}\mathbf{P} \\
\text { Value }\end{array}$} \\
\hline & & $\begin{array}{l}\text { No Job } \\
\text { Stress } \\
\text { N (\%) }\end{array}$ & $\begin{array}{l}\text { Low Amount of } \\
\text { Job-Related } \\
\text { Stress } \\
\text { N (\%) }\end{array}$ & $\begin{array}{l}\text { Moderate } \\
\text { Amount of } \\
\text { Stress on the } \\
\text { Job } \\
\mathrm{N}(\%)\end{array}$ & $\begin{array}{l}\text { High Amount of } \\
\text { Job-Related } \\
\text { Stress } \\
\mathrm{N}(\%)\end{array}$ & $\begin{array}{l}\text { Total } \\
\text { N (\%) }\end{array}$ & & \\
\hline \multirow{3}{*}{ Male } & $\begin{array}{l}\text { Least } \\
\text { Likely }\end{array}$ & $1(10)$ & $0(0)$ & $0(0)$ & $0(0)$ & $1(1.2)$ & \multirow{3}{*}{$\begin{array}{l}26.27 \\
6 \mathrm{df}\end{array}$} & \multirow{3}{*}{$\begin{array}{l}0.001 \\
* * *\end{array}$} \\
\hline & $\begin{array}{l}\text { More } \\
\text { Likely }\end{array}$ & $9(90)$ & $8(34.8)$ & $12(32.4)$ & $12(32.4)$ & $2(12.5)$ & & \\
\hline & $\begin{array}{l}\text { Most } \\
\text { Prone } \\
\text { Stress }\end{array}$ & $0(0)$ & $15(65.2)$ & $25(67.6)$ & $14(87.5)$ & $54(62.8)$ & & \\
\hline \multirow{3}{*}{ Female } & $\begin{array}{l}\text { Least } \\
\text { Likely }\end{array}$ & $2(11.1)$ & $0(0)$ & $0(0)$ & $0(0)$ & $2(1.3)$ & \multirow{3}{*}{$\begin{array}{l}38.06 \\
6 \mathrm{df}\end{array}$} & \multirow{3}{*}{$\begin{array}{l}0.001 \\
* * *\end{array}$} \\
\hline & $\begin{array}{l}\text { More } \\
\text { Likely }\end{array}$ & $14(77.8)$ & $14(34.1)$ & $22(27.5)$ & $2(13.3)$ & $52(33.8)$ & & \\
\hline & $\begin{array}{l}\text { Most } \\
\text { Prone } \\
\text { Stress }\end{array}$ & $2(11.1)$ & $27(65.9)$ & $58(72.5)$ & $13(86.7)$ & $100(64.9)$ & & \\
\hline
\end{tabular}

***There is a more difference between the stress levels and burnout levels among the male at $95 \%(\mathrm{p}<0.05)$.

Table 3, shows that least likely value is $1.7 \%$ in private school and $0.8 \%$ in the government school there is not much difference, more likely value is $36.7 \%$ in the private school at the same time $32.5 \%$ in the government school there is some difference but not a statistical difference, most prone stress is $61.6 \%$ in the private school but $66.7 \%$ in the government school here also have some difference not a statistical difference among the stress levels.

Table 3. Determine the occupational stress in special school teachers by using the questionnaire in the private school and Government School

\begin{tabular}{lllll}
\hline Stress & $\begin{array}{l}\text { Private School } \\
\text { N (\%) }\end{array}$ & $\begin{array}{l}\text { Government School } \\
\text { N (\%) }\end{array}$ & Chi Square Test & P Value \\
\hline Least Likely & $2(1.7)$ & $1(0.8)$ & & \\
More Likely & $44(36.7)$ & $39(32.5)$ & 0.868 & 0.648 \\
Most Prone Stress & $74(61.6)$ & $80(66.7)$ & $2 \mathrm{df}$ & NS \\
Total & $120(100)$ & $120(100)$ & & \\
\hline
\end{tabular}

NS - Not statistical significance association between the Private and Government school using the chi square test among the Stress levels $\mathrm{p}=0.648$ (i.e. $\mathrm{p}>0.05$ ).

From the Table 4, comparison of stress levels among the private school lease likely $4.00 \pm 1.41$. Most likely $9.86 \pm$ 2.29 and most prone stress $15.66 \pm 1.34$ using ANOVA test get statistical significance difference $\mathrm{p}=0.001(\mathrm{p}<$ 0.05). Comparison of stress levels among the government school lease likely $5.00 \pm 0.00$, Most likely $10.82 \pm 1.99$ and most prone stress $16.15 \pm 1.84$ using ANOVA test get statistical significance difference $p=0.001(p<0.05)$. 
Table 4. Compare the occupational stress in special school teachers by using the questionnaire in the private school and Government School

\begin{tabular}{|c|c|c|c|c|c|c|c|c|c|c|}
\hline \multirow{2}{*}{ Stress } & \multicolumn{5}{|c|}{ Private School } & \multicolumn{5}{|c|}{ Government School } \\
\hline & $\mathrm{N}$ & Mean & SD & ANOVA & P Value & $\mathrm{N}$ & Mean & SD & ANOVA & P Value \\
\hline Least Likely & 2 & 4.00 & 1.41 & \multirow{4}{*}{180.74} & & 1 & 5.00 & - & \multirow{4}{*}{116.51} & \\
\hline More Likely & 44 & 9.86 & 2.29 & & 0.001 & 39 & 10.82 & 1.99 & & 0.001 \\
\hline Most Prone Stress & 74 & 15.66 & 1.34 & & $* * *$ & 80 & 16.15 & 1.84 & & $* * *$ \\
\hline Total & 120 & 13.34 & 3.51 & & & 120 & 14.33 & 3.24 & & \\
\hline
\end{tabular}

*** There is statistical significance difference among the groups at $95 \%(\mathrm{p}<0.05)$.

From the Figure 1 easy to understand that there is small difference between the private and government school but not a statistical difference from the bar diagram. Table 5, Shows that least likely value is $19.2 \%$ in the private school and $4.2 \%$ in the government school there is statistical difference, more likely value is $34.2 \%$ in the private school at the same time $19.2 \%$ in the government school there is more statistical difference, most prone stress is $43.3 \%$ in the private school but $54.2 \%$ in the government school here also have some statistical significance difference among the burnout levels.

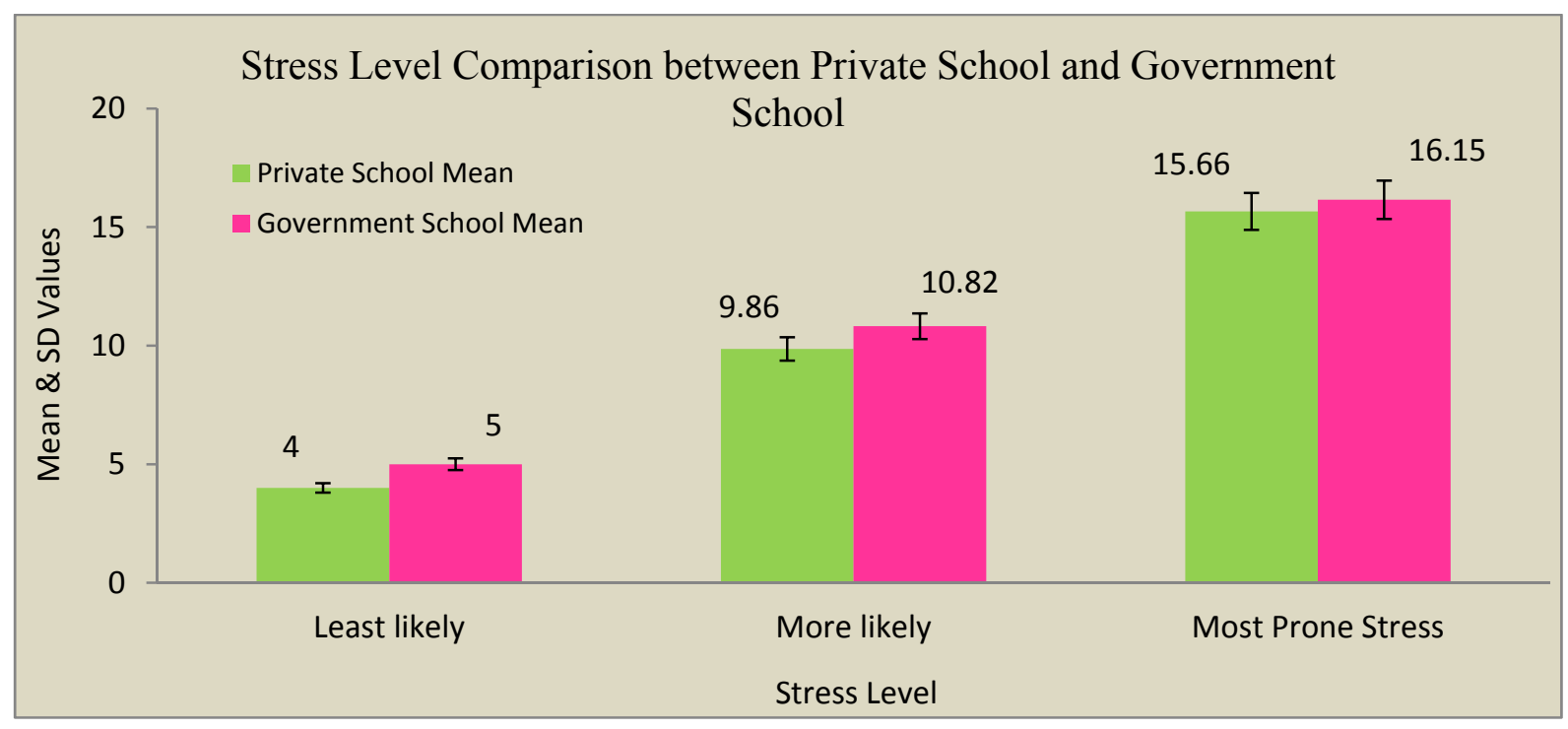

Figure 1. The Comparison between Private School and Government School

Table 5. Determine the professional burnout in special school teachers by using the questionnaire in the government school and Private School

\begin{tabular}{|c|c|c|c|c|c|}
\hline Burnout & $\begin{array}{l}\text { Private School } \\
\text { N (\%) }\end{array}$ & $\begin{array}{l}\text { Government School } \\
\text { N (\%) }\end{array}$ & $\begin{array}{l}\text { Chi } \\
\text { test }\end{array}$ & Square & P Value \\
\hline No Job Stress & $23(19.2)$ & $5(4.2)$ & & & \\
\hline Low Amount of Job-Related Stress & $41(34.2)$ & $23(19.2)$ & 31.14 & & 0.001 \\
\hline Moderate Amount of Stress On The Job & $52(43.3)$ & $65(54.2)$ & $3 \mathrm{df}$ & & $* *$ \\
\hline High Amount of Job-Related Stress & $4(3.3)$ & $27(22.4)$ & & & \\
\hline
\end{tabular}

** - There is a statistical significance association between the Private and Government school using the chi square test among the burnout levels $\mathrm{p}=0.0 .001$ (i.e. $\mathrm{p}<0.05$ ).

Figure 2, shows easy to understand that there is a statistical significance difference between the private and 
government school using the bar diagram. Table 6 , shows comparison of no job stress in the private school $32.22 \pm$ 2.31, Low Amount of Job-Related Stress 42.88 \pm 4.70, Moderate Amount of Job-Related Stress 58.44 4.09 and High Amount of Job-Related Stress $73.75 \pm 2.22$ using ANOVA test get statistical significance difference $\mathrm{p}=$ $0.001(\mathrm{p}<0.05)$. Comparison of no job stress in the government school $32.80 \pm 1.79$, Low Amount of Job-Related Stress $46.17 \pm 6.05$, Moderate Amount of Job-Related Stress 60.15 \pm 5.98 and High Amount of Job-Related Stress $73.89 \pm 2.15$ using ANOVA test get statistical significance difference $p=0.001(p<0.05)$.

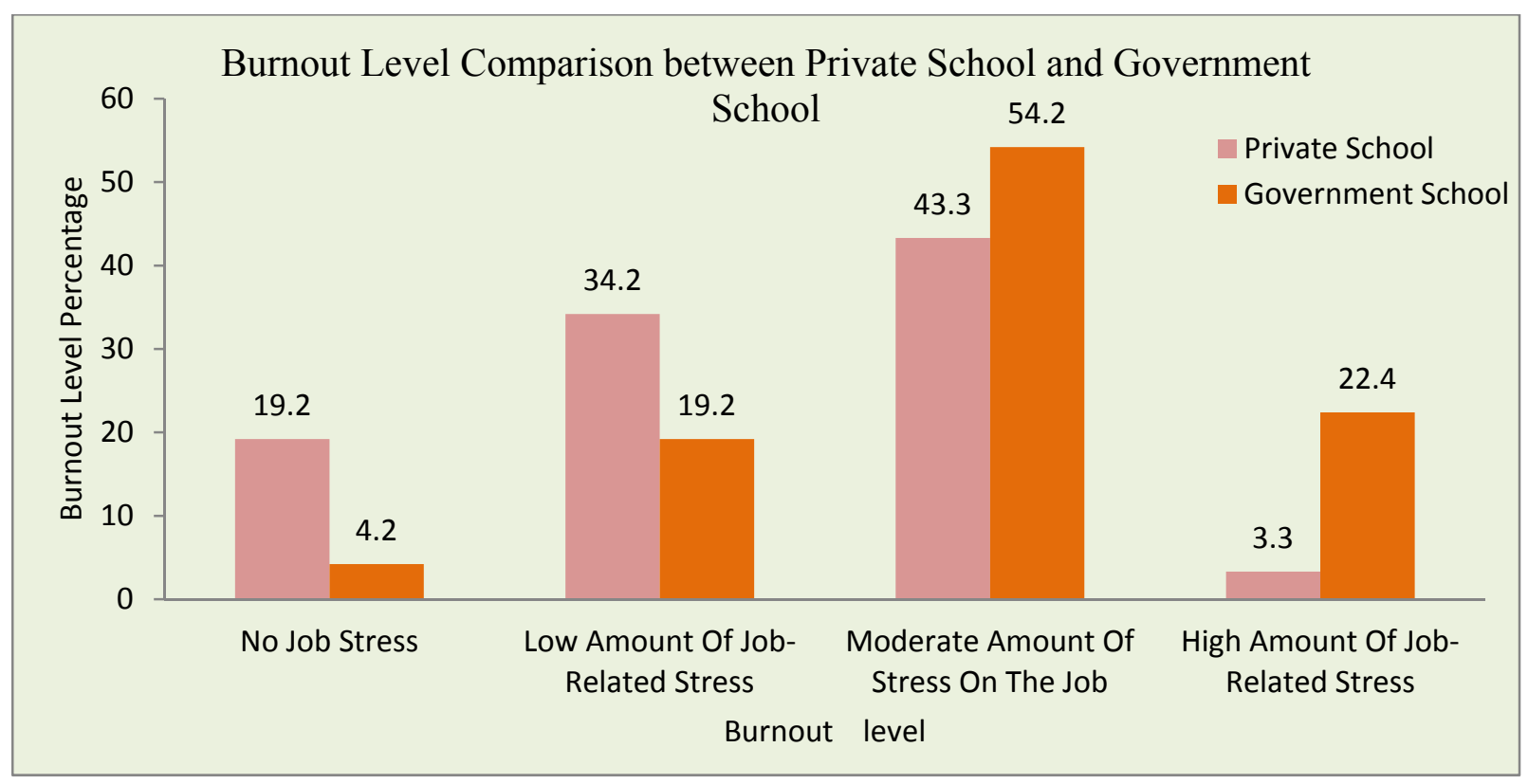

Figure 2. The Burnout Level Comparison between Private School and Government School

Table 6. Compare the some other stress related variables among the private and government schools

\begin{tabular}{|c|c|c|c|c|c|c|c|c|}
\hline \multirow{2}{*}{ Related Stress Variable } & \multicolumn{4}{|c|}{ Private School } & \multicolumn{4}{|c|}{ Government School } \\
\hline & $\mathrm{N}$ & Mean \pm SD & ANOVA & P Value & $\mathrm{N}$ & Mean \pm SD & ANOVA & P Value \\
\hline No Job Stress & 23 & $32.22 \pm 2.31$ & & & 5 & $32.80 \pm 1.79$ & & \\
\hline $\begin{array}{l}\text { Low Amount of } \\
\text { Job-Related Stress }\end{array}$ & 41 & $42.88 \pm 4.70$ & & & 23 & $46.17 \pm 6.05$ & & \\
\hline $\begin{array}{l}\text { Moderate Amount of } \\
\text { Job-Related Stress }\end{array}$ & 52 & $58.44 \pm 4.09$ & 311.56 & $\begin{array}{l}0.001 \\
* * *\end{array}$ & 65 & $60.15 \pm 5.98$ & 158.85 & $\begin{array}{l}0.001 \\
* * *\end{array}$ \\
\hline $\begin{array}{l}\text { High Amount of } \\
\text { Job-Related Stress }\end{array}$ & 4 & $73.75 \pm 2.22$ & & & 27 & $73.89 \pm 2.15$ & & \\
\hline
\end{tabular}

*** - There is a Statistical significance difference within private school among the some Occupational Stress levels at $95 \%$ ( $\mathrm{p}<$ $0.05)$.

From the Figure 3 easy to understand that there is a statistical significance difference between the private and government school using the bar diagram with some related variables are No Job Stress, Low Amount of Job-Related Stress, Moderate Amount of Job-Related Stress and High Amount of Job-Related Stress. Table 7, shows the overall stress comparison between private school and government school for mean and standard deviation are $13.34 \pm 3.51$ and $14.33 \pm 3.24$. Similarly overall Burnout comparison between private school and government school for mean and standard deviation are $48.61 \pm 11.94$ and $59.43 \pm 11.78$. Using the independent $t$ test to get the statistical significance difference in the stress level $p=0.025(p<0.05)$ and burnout is $p=0.001(p<$ $0.01)$. Figure 4 , shows the easy to understand that there is a statistical significance difference between the private and government schools using the bar diagram with overall stress and burnout variables. 


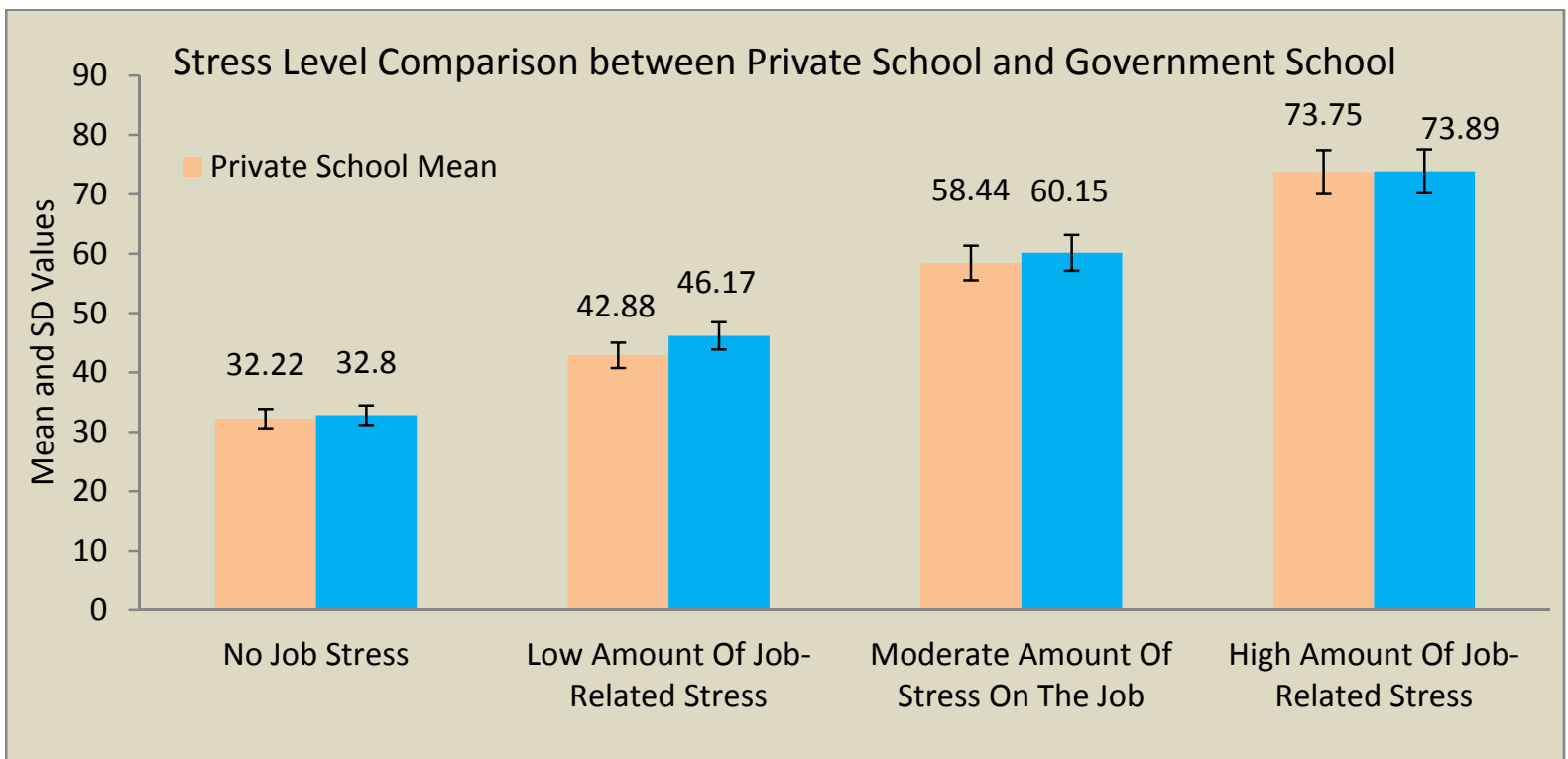

Figure 3. The comparison among the private school and government school how the other variable related with statistical difference

Table 7. To compare the occupational stress/professional burnout in special school teachers working in the Private and Government school

\begin{tabular}{|c|c|c|c|c|c|c|}
\hline \multicolumn{7}{|c|}{ Group Statistics } \\
\hline & Group & $\mathrm{N}$ & Mean & SD & Independent t Test & Sig.Level \\
\hline \multirow{2}{*}{ Stress } & Private School & 120 & 13.34 & 3.51 & \multirow{2}{*}{2.26} & \multirow{2}{*}{$0.025 *$} \\
\hline & Government School & 120 & 14.33 & 3.24 & & \\
\hline \multirow{2}{*}{ Burnout } & Private School & 120 & 48.61 & 11.94 & \multirow{2}{*}{7.07} & \multirow{2}{*}{$0.001 * *$} \\
\hline & Government School & 120 & 59.43 & 11.78 & & \\
\hline
\end{tabular}

*there is a statistical significance difference between private school and government among the stress at $95 \%(\mathrm{p}<0.05)$.

**there is a statistical significance difference between private school and government among the burnout at $99 \%(\mathrm{p}<0.01)$.

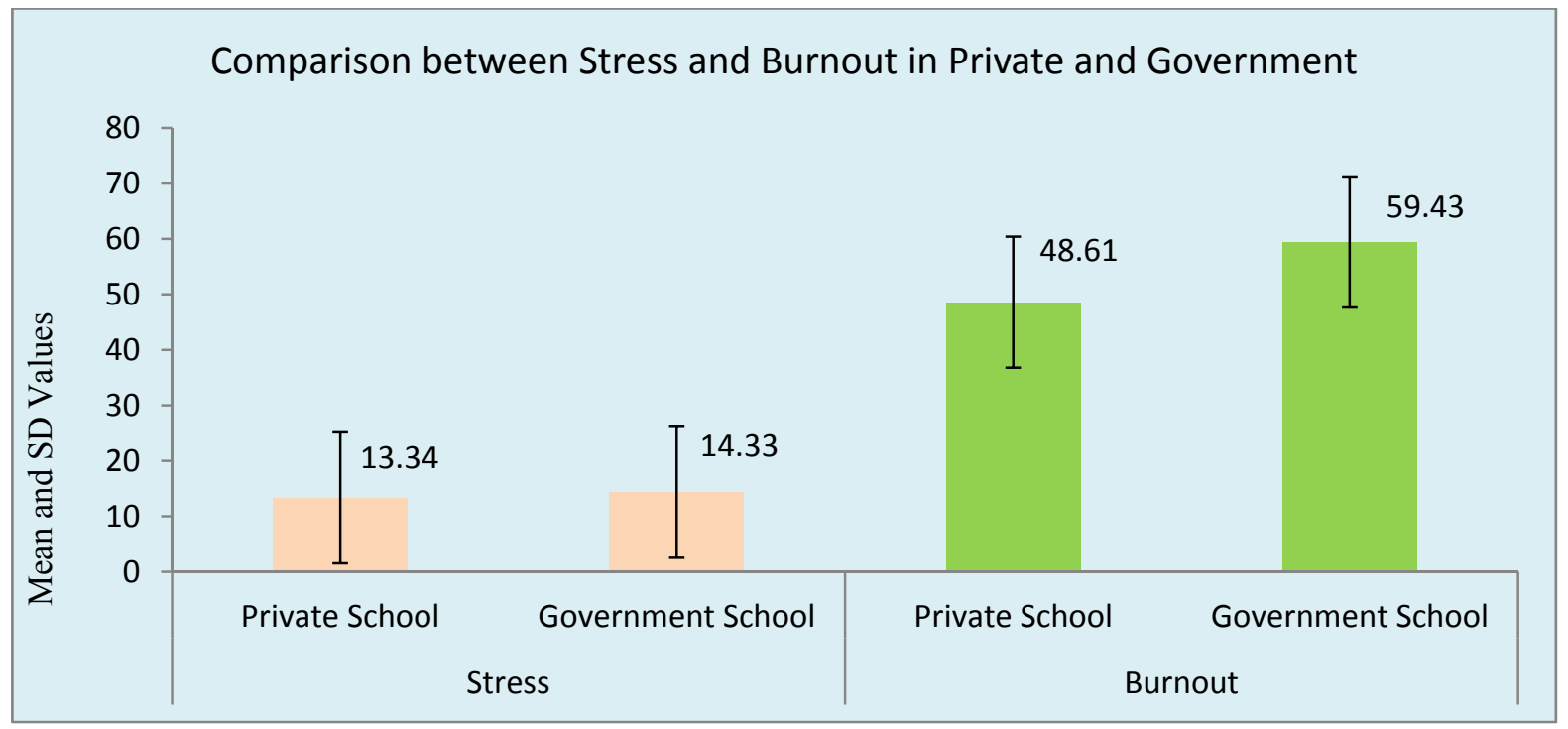

Figure 4. Comparison between Stress and Burnout in the Private and Government schools 


\section{Discussion}

This study has several limtations. Firstly, this is a cross-sectional study and we cannot establish the cause and effect relationship between psychosocial factors and stress (Ho et al., 2011). Stress affects the immunity and causes chronic medical diseases including coronary artery disease (Ho et al., 2010). This study did not report the prevalence of chronic medical diseases which is associated with higher level of stress, poor subjective health and impaired functional status (Niti et al., 2007).

The paper aim is to critical analysis of occupational stress/burnout among the private/government school teacher. Today teaching most stressful professions in the world. Because no similar job to other stressful profession in the world. $75 \%$ of the researcher assessing the stress levels of various jobs, teaching came in the top rank. The report, Occupational Stress: Further analysis of the impact of demographic factors and type of job, published in 2000, found that $41.5 \%$ of teachers reported themselves 'highly stressed', while $58.5 \%$ came into a 'low stress' category, while $36 \%$ of teachers felt the effects of stress all or most of the time. In our study around $36.7 \%$ and $32.5 \%$ of surveyed teachers were moderate to $61.6 \%$ and $66.7 \%$ severe stressful which was not similar to the result of the study in the private/government school teacher by Health and Safety Executive, USA (41.5\%) and with previous study.

Cooper (1991) found the levels of job dissatisfaction and mental ill health higher, In addition, it was found that, with the exception of primary schools, female head teachers in secondary and FHE seem to be suffering significantly greater job dissatisfaction than their male teachers, although this does not translate itself into mental ill health. Male head teachers, on the other hand, seem to suffer more mental ill health than their female teachers. Our study also found that both male and female teachers are having stressed. Our study found that female teachers were less stressful than male teachers which were not similar to findings of Klassen. Our study also proved that teachers with higher workload (Headmaster and Assistant Headmaster) were more stressed.

Millicent (2010) Examined Sources of stress and symptoms of burnout in 51 rural and 46 urban secondary school teachers from 11 school systems in Georgia and North Carolina. In our study the private school teachers significantly more stress from poor working conditions and poor staff relations than did government school teachers. Stress from pupil misbehavior and time pressures was significantly greater than stress from poor working conditions for both private/government school teachers. Poor working conditions and time pressures predicted burnout for private school teachers; pupil misbehavior and poor working conditions predicted burnout for government school teachers.

Our study found a mean difference in the stress levels among the private school teachers have most prone stress 15.66 at the same time mostly like 9.86 and lease like 4.00 . The mean difference in the stress levels among the government school teachers have most prone stress 16.15, in the most like 10.82 and lease like 5.99 lesser than the private schools

So it justified the stress with workload. Income is a major determining factor behind the stress level of teachers. But our study found that stress level was high in the governmental school teachers than private. It can be explained by the fact that teachers in governmental position like Head Master/ Assistant Head Master got higher salary compare to private, but the reason their stress level was very high. Because of that we need further study required to identify factors that lead to stress and burnout in governmental and private schools.

\section{Conclusion}

Occupational therapist has a major role in stress management. This study helps -To give an insight to occupational therapist about the stress level in Private and Government special school teachers. Occupational therapist can help teachers to improve symptom management ability and problem-focused coping skills to raise their life quality (Tan $\mathrm{SH}$ et al., 2015). Online cognitive behavior therapy to ensure privacy and cost-effectiveness for teachers (Zhang et al., 2017). To create awareness for Policy makers make early identification and counseling about different factors that influence stress level in private and Government school teachers.

Teaching is quite stressful occupation because increased age and other problems, female sex are non-modifiable stress factors whereas increased remuneration and decreased time to commute to schools can cause decreased stress which is potentially modifiable. A regular increment in remuneration and relocation according to place of residence can decrease the stress level. For female teachers, helping hand from their spouses in household chores may just be a big difference. Sharing responsibility of administrative duties between teachers can decrease the stress level of administrators. 


\section{Competing Interests Statement}

The authors declare that they have no competing or potential conflicts of interest.

\section{References}

Akcamete, G., Kaner, S., \& ve Sucuoğlu, B. (2001). Öğretmenlerde tükenmişlik iş do you've Kişilik. Ankara: Nobel Yayın Dağıtım.

Alexander, D., Gaillard, J. C., \& Wisner, B. (2012). Disability and disaster, I eds. Handbook of hazards and disaster risk reduction (pp. 413-423). London, Routledge.

Allen, R. D., Hitt, M. A., \& Greer, C. R. (1982). Occupational stress and perceived organizational effectiveness in formal groups: An examination of stressor level and stressor type. Personnel Psychology, 35, 359-370. https://doi.org/10.1111/j.1744-6570.1982.tb02201.x

Amirtagowri, R., \& Thiagarajan, A. P. (2005). Occupational dilemmas of educational women- an analysis. $\begin{array}{lllll}\text { Perspectives of } & \text { Education, } & \text { 21(3), } & 175-183 . & \text { Retrieved }\end{array}$ http://shodhganga.inflibnet.ac.in/bitstream/10603/25562/12/12_conclusion.pdf

Anbu, V. (2015). The effect of Cognitive Behavior Therapy and Yoga Therapy for Pregnant Women. J Yoga Phys Ther, 5, 184. https://doi.org/10.4172/2157-7595.1000184

Ansarul, H. (2014). A Study of Occupational Stress of Primary School Teachers. Educationia Confab, 3(4), 11-19. Retrieved from https://pdfs.semanticscholar.org/adbc/9c6c182c899fcc302a56e254b8fa0bfada96.pdf

Bhagat, R. S., Steverson, P. K., \& Segovis, J. C. (2007). International and cultural variations in employee assistance programmes: Implications for managerial health and effectiveness. Journal of Management Studies, 44(2), 222-242. https://doi.org/10.1111/j.1467-6486.2007.00686.x

Bram P. B., \& Wilmar, B. S. (1999). Reciprocity in interpersonal relationships: an evolutionary perspective on its importance for health and well-being. European Review of Social Psychology, 10(1), $259-291$. https://doi.org/10.1080/14792779943000080

Buunk, B. P. (1998). Social comparison and optimism about one's relational future: order effects in social judgment. European Journal of Social Psychology, 28(5), 777-786. https://doi.org/10.1002/(SICI)1099-0992(199809/10)28:5<777::AID-EJSP892>3.0.CO;2-O

Chaly, P. E., Anand, P. J. S., Reddy, V. C. S., Nijesh, J. E., \& Srinidhi, S. (2014). Evaluation of occupational stress among software professionals and school teachers in trivandrum. International journal of medical and dental science, 3(2), 440. https://doi.org/10.19056/ijmdsjssmes/2014/v3i2/81283

Chopra, R., \& Gartia, R. (2009). Accountability of secondary school teachers in relation to their occupational stress, Edu. Tracks, 8 (7), 41-43.

Cooper, C. L., \& Payne, R., (1991). Personality and stress: individual differences in the stress process. John Wiley \& Sons Ltd. http://psycnet.apa.org/record/1991-98989-000

Cuttilan, A. N., Sayampanathan, A. A., \& Ho, R. C. (2016). Mental health issues amongst medical students in asia: A systematic review [2000-2015]. Annals of Translational Medicine, 4(4), 72. PMID:27004219.

Cydulka, R. K., Lyons, J., Moy, A., Shay, K., Hammer, J., \& Mathews, J. (1989). A follow-up report of occupational stress in urban emt-paramedics. Annals of Emergency Medicine, 18(11), 1151. https://doi.org/10.1016/S0196-0644(89)80050-2

Detert, R. A., Derosia, C., Caravella, T., \& Duquette, D. (2006). Reducing stress and enhancing the general wellbeing of teachers using T'ai Chi Chih movements: A pilot study. Californian Journal of Health Promotion, 4(1), 162-173. Retrieved from http://www.cjhp.org/Volume4_2006/documents/162173-detert.pdf

Hasan, A. (2014). A Study of Occupational Stress of Primary School Teachers. Educational Confab, 3(4).

Ho, R. C., Mak, K. K., Chua, A. N., Ho, C. S., \& Mak, A. (2013). The effect of severity of depressive disorder on economic burden in a university hospital in singapore. Expert Review of Pharmacoeconomics \& Outcomes Research, 13(4), 549.

Ho, R. C. M., Fu, E. H. Y., Chua, A. N. C., Cheak, A. A. C., \& Mak, A. (2011). Clinical and psychosocial factors associated with depression and anxiety in singaporean patients with rheumatoid arthritis. International Journal of Rheumatic Diseases, 14(1), 37-47. PMID: 21303480. 
https://doi.org/10.1111/j.1756-185X.2010.01591.x

Ho, R. C., Neo, L. F., Chua, A. N., Cheak, A. A., \& Mak, A. (2010). Research on psychoneuroimmunology: does stress influence immunity and cause coronary artery disease?. Annals of the Academy of Medicine Singapore, 39(3), 191. PMID:20372754.

Ho, R. C., Neo, L. F., Chua, A. N., Cheak, A. A., \& Mak, A. (2010). Research on psychoneuroimmunology: does stress influence immunity and cause coronary artery disease?. Annals of the Academy of Medicine Singapore, 39(3), 191.

Jepson, E., \& Forrest, S. (2006). Individual contributory factors in teacher stress: the role of achievement striving and occupational commitment. British Journal of Educational Psychology, $76(\mathrm{Pt} 1), 183$. https://doi.org/10.1348/000709905X37299

Kaur, M., \& Kaur, S., (2007). Occupational stress and burnout among women police. Journal of Community Guidance and Research, 24(3), 262-265.

Kumar, N. (2007). Influence of certain psycho-sociological factors on the occupational stress among the public and private school teachers of Orissa (Ph.D. Thesis submitted to Utkal University).

Kyriacou, C., (2001).Teacher Stress: Directions for Future Research. Educational Review, 53(1), 27-35. https://doi.org/10.1080/00131910120033628.

Lee, Y., Rosenblat, J. D., Lee, J., Carmona, N. E., Subramaniapillai, M., \& Shekotikhina, M., et al. (2017). Efficacy of antidepressants on measures of workplace functioning in major depressive disorder: a systematic review. Journal of Affective Disorders, 227, 406. PMID: 29154157.

Luthans, F., Avolio, B. J., Avey, J. B., \& Norman, S. M. (2007). Positive psychological capital: measurement and relationship with performance and satisfaction. Personnel Psychology, 60(3), 541-572.

Lu, Y., Ho, C. S., Liu, X., Chua, A. N., Wang, W., \& Mcintyre, R. S., \& Ho, R. C. (2017). Chronic administration of fluoxetine and pro-inflammatory cytokine change in a rat model of depression. Plos One, 12(10), e0186700. https://doi.org/10.1371/journal.pone.0186700

Lu, Y., Tang, C., Liow, C. S., Ng, W. W. N., Ho, C. S. H., \& Ho, R. C. M. (2014). A regressional analysis of maladaptive rumination, illness perception and negative emotional outcomes in asian patients suffering from depressive disorder. Asian Journal of Psychiatry, 12(1), 69-76. https://doi.org/10.1016/j.ajp.2014.06.014

Maslach, C., \& Jackson, S. E. (1981). The measurement of experienced burnout. Journal of Organizational Behavior, 2(2), 99-113. https://doi.org/10.1002/job.4030020205

Abel, M. H., \& Sewell, J. (1999). Stress and burnout in rural and urban secondary school teachers. Journal of Educational Research, 92(5), 287-293. https://doi.org/10.1080/00220679909597608

Naina, S., Deeya, A., Mohit, G., \& Arjun, H. (2015). A study on occupational stress among faculty members in Higher Education Institutions in Pune. (SIMSJMR) SIMS Journal of Management Research, 1, 18-23. Retrieved from https://www.sims.edu/wp-content/uploads/2015/04/5_SIMSJMR_Iss1_Paper3_Pg18-23.pdf

Niti, M., Ng, T. P., Kua, E. H., Ho, R. C., \& Tan, C. H. (2007). Depression and chronic medical illnesses in asian older adults: the role of subjective health and functional status. International Journal of Geriatric Psychiatry, 22(11), 1087. https://doi.org/10.1002/gps.1789

Olive, T. B., Enose, M. W., Simatwa, \& Julius, O. G. (2016). Levels of Stress among Secondary School Teachers and its Implication on Students' Academic Performance in Kenya: A Case Study of Kakamega North Sub County. Greener Journal of Educational Research, 6(2), 52-66.

Oshagbemi, T., (2000). Correlates of pay satisfaction in higher education. The International Journal of Educational Management, 14, 95- 107. https://doi.org/10.1108/09513540010310387

Poornima, B., Shveta, K., \& David, E. O. (2012). Looking within: self-perceived professional strengths and limitations of psychotherapists in India. Asia Pacific Journal of Counselling and Psychotherapy, 3(2), 161-174. https://doi.org/10.1080/21507686.2012.703957

Reddy, G. L., \& Poornima, R. (2012). Occupational stress and professional burnout of University teachers in South India. International Journal of Educational Planning \& Administration, 2(2), 109-124. Retrieved from http://www.ripublication.com/ijepa.htm

Reddy, G. L. (2007). Occupational stress, professional burnout and job satisfaction of special education teachers, Major Research Project (Report Submitted to Ministry of Social Justice and Empowerment, Govt., of India, 
New Delhi), Dept., of Education, Periyar University, Salem.

Reddy, G. L., \& Poornima, R. (2009). A study on occupational stress of teachers working in the special schools for visually impaired children. Disabilities and Impairments, 23(1), 7-18.

Sapna, \& Ved Prakash, G. (2013). Occupational stress among the engineering college teachers in Punjab, India, International Journal of Education and Applied Research, 3(1).

Selye, H. (1950). Annual report on Stress. Acta Medical Publisher, Montreal, 1-127, Surinder Kaur., (2011). Comparative Study of Occupational Stress among Teachers of Private and Govt. Schools in Relation to their Age, Gender and Teaching Experience. International Journal of Educational Planning \& Administration, 1(2), 151-160.

Sumanta, D., Payel, T., Subir, B., Om Prakash, S. (2016). A Study on Job related Stress among School Teachers in Different Schools of West Bengal, India. Eastern Journal of Psychiatry, 19(1), 12-17. Retrieved from http://easternjpsychiatry.org/index.php/about/article/view/49/46

Tan, S. H., Tang, C., Ng, W. W., Ho, C. S., \& Ho, R. C. (2015). Determining the quality of life of depressed patients in singapore through a multiple mediation framework. Asian Journal of Psychiatry, 18, 22-30. https://doi.org/10.1016/j.ajp.2015.10.010

Sunanda, K. (2017). Stress Among Higher Secondary School Teachers - With Reference To Corporate Schools In Hyderabad. International Conference On Emerging Trends I Engineering, Science And Management, 45-55.

Yang, J. L., Liu, D. X., Jiang, H., Pan, F., Ho Cyrus, S. H., \& Ho Roger, C. M. (2016). The effects of high-fat-diet combined with chronic unpredictable mild stress on depression-like behavior and leptin/leprb in male rats: Scientific Reports, 6, 35239. PMID: 27739518. https://doi.org/10.1038/srep35239

Yeo, S. N., Zainal, H., Tang, C. S., Tong, E. M., Ho, C. S., \& Ho, R. C. (2017). Success/failure condition influences attribution of control, negative affect, and shame among patients with depression in singapore. Bmc Psychiatry, 17(1), 285. PMID: 28768488. https://doi.org/10.1186/s12888-017-1451-7

Zhang, M. W., \& Ho, R. C. (2016). Moodle: the cost effective solution for internet cognitive behavioral therapy (i-cbt) interventions. Technology \& Health Care, 25(1). PMID: 27689560 https://doi.org/10.3233/THC-161261

\section{Appendix}

Table 1. Demographical Table

\begin{tabular}{lllll}
\hline & & Private School & Government School & Total \\
& $\mathrm{N}(\%)$ & $\mathrm{N}(\%)$ & $\mathrm{N}(\%)$ \\
\hline \multirow{2}{*}{$20-30$ Years } & Male & $34(42)$ & $31(36.5)$ & $65(39.2)$ \\
& Female & $47(58)$ & $54(63.5)$ & $101(60.8)$ \\
\hline \multirow{2}{*}{$31-40$ Years } & Male & $9(37.5)$ & $11(40.7)$ & $20(39.2)$ \\
& Female & $15(62.5)$ & $16(59.3)$ & $31(60.8)$ \\
\hline \multirow{2}{*}{$41-50$ Years } & Male & - & - & - \\
& Female & $7(100)$ & $4(100)$ & $11\left(100_{-}\right.$ \\
\hline \multirow{2}{*}{$51-60$ Years } & Male & $0(0)$ & $1(25)$ & $1(8.3)$ \\
& Female & $8(100)$ & $3(75)$ & $11(91.7)$ \\
\hline
\end{tabular}

All correction done by the author in the Yellow colour marking in the document.

\section{Copyrights}

Copyright for this article is retained by the author(s), with first publication rights granted to the journal.

This is an open-access article distributed under the terms and conditions of the Creative Commons Attribution license (http://creativecommons.org/licenses/by/4.0/). 